\title{
EFFECT OF CONCENTRATION AND N:K RATIO IN NUTRIENT SOLUTION FOR HYDROPONIC PRODUCTION OF CUCUMBER ${ }^{1}$
}

\author{
DEISE SILVA CASTRO PIMENTEL CARDOSO ${ }^{2 *}$, MARIA APARECIDA NOGUEIRA SEDIYAMA ${ }^{3}$, YONARA \\ POLTRONIERI $^{3}$, MAIRA CHRISTINA MARQUES FONSECA ${ }^{3}$, YANE FERNANDES NEVES ${ }^{4}$
}

\begin{abstract}
The N:K ratio influences the balance between vegetative and reproductive stages, because potassium plays important roles in the processes that regulate plant growth when the nitrogen availability is high. However, there is a lack of information on the $\mathrm{N}: \mathrm{K}$ ratio suitable for cucumber cultivation in an NFT-hydroponic system. The objective of this study is to evaluate the different $\mathrm{N}: \mathrm{K}$ ratios in fruiting nutrient solutions for cucumber production in a hydroponic system. Treatments consisted of two cucumber hybrids (Natsuno Kagayaki and Runner) and four nutrition solutions with different N:K ratios (w/w) (1:0.5, 1:1.0, $1: 2.0$, and 1:3.0) in the reproductive phase arranged as split plots in a randomized block design with four replications. On the $33^{\text {rd }}$ day after sowing (DAS), the SPAD index on the fourth expanded leaf from the plant apex, number of broaches, and harvests were evaluated. The aerial parts of the plants were collected on the $54^{\text {th }}$ DAS for evaluation of fresh mass, dry mass, and number of leaves per plant. The results showed that the highest concentration of $\mathrm{K}$ in the fruiting nutrient solution does not alter the length of the fruits but increases their diameter yield. The $\mathrm{N}: \mathrm{K}$ ratios in the 1:2.0 and 1:3.0 (w/w) nutrient solutions provided greater yields in both evaluated hybrids. The hybrid Natsuno Kagayaki, however, showed the highest productivity, and it is recommended for hydroponic cultivation.
\end{abstract}

Keywords: Cucumis sativus. Hybrids. SPAD index. Potassium.

\section{EFEITO DA CONCENTRAÇÃO E DA RELAÇÃO N:K DA SOLUÇÃO NUTRITIVA PARA PRODUÇÃO DE PEPINO HIDROPÔNICO}

\begin{abstract}
RESUMO - A relação N:K influencia o equilíbrio entre as fases vegetativa e reprodutiva, pois o potássio atua em processos que ajudam a regular o crescimento das plantas, quando a disponibilidade de nitrogênio é elevada. No entanto, há carência de informações sobre relações $\mathrm{N}: \mathrm{K}$ adequadas para o cultivo do pepino em sistema hidropônico-NFT. Objetivou-se com esse trabalho avaliar diferentes relações N:K da solução nutritiva de frutificação para produção de pepino em sistema hidropônico. Os tratamentos foram dois híbridos de pepino (Natsuno Kagayaki e Runner) e quatro soluções nutritivas com diferentes relações N:K (p/p) (1:0,5; 1:1,0; 1:2,0 e 1:3,0) na fase de reprodutiva, arranjados como parcelas subdivididas, no delineamento em blocos casualizados com quatro repetições. Aos 33 dias após a semeadura (DAS) avaliou-se o índice SPAD, na quarta folha expandida, a partir do ápice da planta, o número de brotações e teve inicio as colheitas. Coletou-se a parte aérea das plantas para avaliação de massa fresca, massa seca e número de folhas por planta aos 54 DAS. Os resultados demonstraram que a maior concentração de $\mathrm{K}$ na solução nutritiva de frutificação não altera o comprimento dos frutos, mas aumenta o diâmetro e a produtividade. As relações de $\mathrm{N}: \mathrm{K}$ na solução nutritiva de $1: 2,0$ e 1:3,0 (p/p) proporcionaram maiores produtividades para os híbridos estudados. Entretanto, o híbrido Natsuno Kagayaki apresentou maior produtividade, sendo o mais recomendado para o cultivo hidropônico.
\end{abstract}

Palavras-chave: Cucumis sativus. Híbridos. Índice SPAD. Potássio.

\footnotetext{
${ }^{*}$ Corresponding author

${ }^{1}$ Received for publication in 06/10/2015; accepted in 12/15/2016.

${ }^{2}$ Department of Plant Science, Universidade Federal de Viçosa, Viçosa, MG, Brazil; deiselpimentel@yahoo.com.br.

${ }^{3}$ Empresa de Pesquisa Agropecuária de Minas Gerais, Viçosa, MG, Brazil; marians@epamig.br, yonarapoltronieri@hotmail.com, maira@epamig.br.

${ }^{4}$ Department of Phytopathology, Universidade Federal de Viçosa, Viçosa, MG, Brazil; yane.neves@ufv.br.
} 


\section{INTRODUCTION}

The cucumber (Cucumis sativus L.) is a plant of the Cucurbitaceae family, which presents better development in conditions of high temperature, luminosity, and high-quality supply of nutrients. These characteristics promote adaptation to the protected crop and to the hydroponic system, with possibilities of fruit production during the off season, since the effects of low temperatures and rainfall are minimized. The high productivity of the plants in a hydroponic system is due to the direct supply of water and nutrients, which must be adequate to the stages of the production process, since the nutritional status influences the biomass production and fruit quality (MARTINS et al., 2009).

In the hydroponic cultivation of leafy vegetables, use of the same nutrient solution formulation over the crop cycle is common. The process is more complex in fruiting vegetables, since it involves the vegetative and reproductive phases, and it is sometimes necessary to adapt the nutrient solution to the phases of the crop. Therefore, it is recommended to associate the concentration of the solution and the relationship between the nutrients with the phases of growth and development of the culture (PEDROSA et al., 2011).

The composition of the nutrient solution is one of the most important aspects in obtaining high-quality vegetable products, because it is the means through which nutrients dissolved in the water are placed at the disposal of the plants (MARTINEZ; SILVA FILHO, 1997). Nitrogen is important for the growth and development of plants by altering the source-sink relationship and, consequently, the distribution of assimilates between vegetative and reproductive organs (QUEIROGA et al., 2007). Potassium is the macronutrient most extracted by most vegetables, and it plays an important role in photosynthesis, formation and translocation of carbohydrates, and efficient use of water by the plant (AQUINO et al., 2009). In addition, it improves the quality and weight gain of the fruits and, consequently, their market value (FILGUEIRA, 2008). Potassium deficiency causes a reduction in photosynthetic rate and an increase in respiration, resulting in a decrease in carbohydrate accumulation and fruit quality (NOVAIS et al., 2007).

During analysis of plant nutrient requirements for cultivation in nutritional solution, the focus is on the relationships between nutrients, as this is an indication of the relationship of extraction of the growth medium (FURLANI et al., 1999). Thus, establishing suitable $\mathrm{N}: \mathrm{K}$ ratios in the growing stages of cucumber is one of the factors that affects its productive behavior. The $\mathrm{N}: \mathrm{K}$ ratio determines the balance between vegetative and reproductive phases, since $\mathrm{K}$ acts on growth regulation when $\mathrm{N}$ availability is high (ACOSTA et al., 2011). Pedrosa et al. (2011) found that the use of different $\mathrm{N}: \mathrm{K}$ ratios in the fruiting phase influences cucumber production. The authors recommend an $\mathrm{N}: \mathrm{K}(\mathrm{w} / \mathrm{w})$ ratio of $1.0: 1.7$, with $10 \%$ of $\mathrm{N}$ in the ammoniac form, over the cycle.

Considering the lack of information on the hydroponic cultivation of cucumber, the objective of this work was to evaluate the performance of two cucumber hybrids, one from the Japanese group and the other from the Aodai group, in the reproductive phase of the NFT-hydroponic system within four nutrient solutions with different $\mathrm{N}: \mathrm{K}$ ratios.

\section{MATERIAL AND METHODS}

The experiment was carried out in a protected environment in Viçosa, state of Minas Gerais, from October 24 to December 12, 2014. An arch-type greenhouse was used with the following characteristics: dimensions of $7.0 \times 16.0 \mathrm{~m}\left(112 \mathrm{~m}^{2}\right)$; ceiling and central heights of 3.2 and $4.7 \mathrm{~m}$, respectively; front and side closed with mosquito-type nylon net; covered with PEBD film with $150 \mu \mathrm{m}$ of thickness, with anti-drip and anti-UV properties.

The experiment was conducted in a split plot design, in which solutions were in the plots and the hybrids in the subplots, in a randomized block design with four replications. The plots consisted of four nutrient solutions with the following ratios: $\mathrm{N}: \mathrm{K}=1: 0.5,1: 1.0,1: 2.0$, and 1:3.0. The subplots consisted of two cucumber hybrids, one from the Japanese group (Natsuno Kagayaki F1) and the other from the Aodai group (Runner). Each subplot was composed of six plants spaced by $0.8 \mathrm{~m}$ between rows, that is, between hydroponic profiles and $0.5 \mathrm{~m}$ between plants, in the same profile. In the vegetative phase, a single solution with an $\mathrm{N}: \mathrm{K}(\mathrm{w} / \mathrm{w})$ ratio of $1: 1.4$ was used, and in the reproductive phase, in full blooming of the plants, the solution was replaced with solutions with the four $\mathrm{N}: \mathrm{K}$ ratios described above.

In order to record the internal environmental variables (average daily temperature in ${ }^{\circ} \mathrm{C}$ and air humidity in \%), three Data Loggers (HOBO, U14-001) sensors were randomly positioned inside the greenhouse at $1.0 \mathrm{~m}$ from the ground, with a record interval every 1 minute. In the external area, the sensor was set in a meteorological shelter at $1.5 \mathrm{~m}$ above the ground surface. The mean values of temperature and relative humidity inside and outside the greenhouse were within the range suitable for cucumber cultivation (Figure 1). 


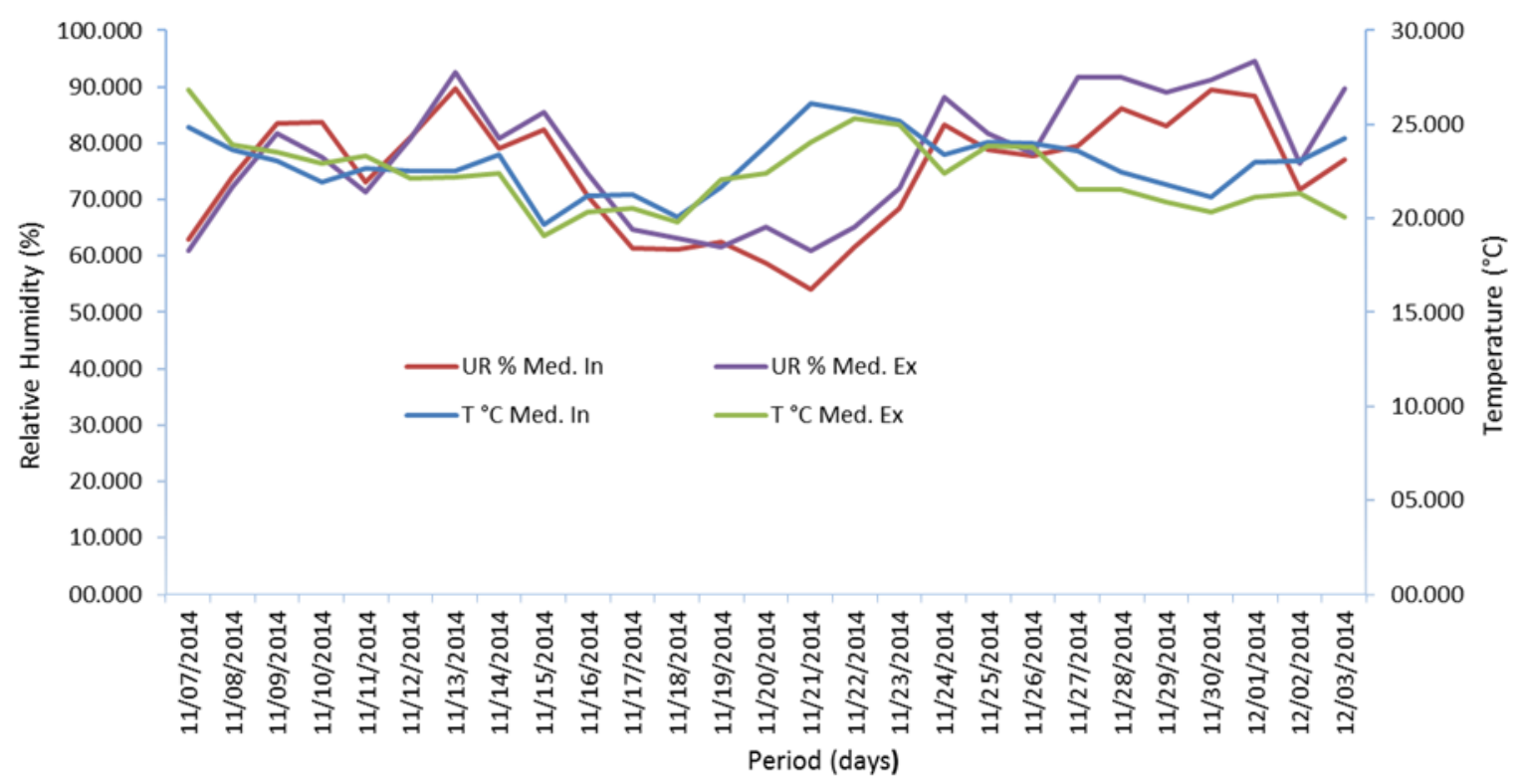

Figure 1. Average values of temperature $\left({ }^{\circ} \mathrm{C}\right)$ and relative air humidity $(\%)$ inside the greenhouse and outer environment.

The seedlings were produced in phenolic foam $(4 \times 4 \times 4 \mathrm{~cm})$ and irrigated with water until germination. Then, they were placed on a growth tray and irrigated with nutrient solution by submersion for 15 days and then transferred to the hydroponic profiles. The NFT-hydroponic technique was used, with intermittent irrigation interval every 15 minutes, controlled by a timer.

The solutions used for the growth and development of cucumber were calculated according to recommendations for tomato (ADAMS, 1994), with the following concentrations: $8,2,4,2,1$, and 1 $\mu \mathrm{mol} \mathrm{L}^{-1}$ of $\mathrm{N}, \mathrm{P}, \mathrm{K}, \mathrm{Ca}, \mathrm{Mg}$, and $\mathrm{S}$, respectively, and $35,19,21,4,0.9$, and $0.7 \mu \mathrm{mol} \mathrm{L}^{-1}$ of Fe, Mn, B, Zn, $\mathrm{Cu}$, and Mo, respectively. In addition, fruiting nutritional solutions were $12,3,8.6,3,1.5$, and $1.5 \mu \mathrm{mol} \mathrm{L}^{-1}$ of $\mathrm{N}, \mathrm{P}, \mathrm{K}, \mathrm{Ca}, \mathrm{Mg}$, and $\mathrm{S}$, respectively, and $59,28,31,4,1.3$, and $0.7 \mu \mathrm{mol} \mathrm{L}^{-1}$ of $\mathrm{Fe}, \mathrm{Mn}$, $\mathrm{B}, \mathrm{Zn}, \mathrm{Cu}$, and $\mathrm{Mo}$, respectively.

Each solution was prepared individually, that is, the fertilizer salts were weighed separately, dissolved, and added to each water reservoir, with a capacity of $300 \mathrm{~L}$. The water volume in the reservoir was completed daily. The $\mathrm{pH}$ was monitored and adjusted with $\mathrm{NaOH}$ or $1 \mathrm{M} \mathrm{HCl}$, keeping it between 5.5 and 6.5. The electric conductivity of the nutrient solution was adjusted whenever the depletion was higher than $30 \%$. In the solution used in the reproductive phase, the EC was approximately 1.5, 2.0, 2.5, and $2.5 \mathrm{dS} \mathrm{m}^{-1}$ for the following concentrations of $\mathrm{N}: \mathrm{K}(\mathrm{w} / \mathrm{w}): 1: 0.5,1: 1.0,1: 2.0$, and $1: 3.0$, respectively.

Milk is used in organic agricultureand have been spraying $5 \%$ cow milk once a week to control powdery mildew on cucumber (BETTIOL; ASTIARRAGA; LUIZ, 1999). The applications were performed in the afternoon with a $1,000 \mathrm{~mL}$ manual spray with thin jets.

The plants were weeded, without pruning or sprout thinning of the branches, with the aid of a wire rope tied to a structure of wood and wire with a height of $1.8 \mathrm{~m}$. At the full bloom of the plants, on the $33^{\text {rd }}$ day after sowing (DAS), the SPAD index, the number of shoots per plant, and the first harvest of the fruits were evaluated. For SPAD index determination, the criterion used for other cucurbitaceae was adopted, i.e., reading on the completely expanded young leaf, which is usually the third or fourth leaf from the apex (GÜLER; BÜYÜK, 2007; PÔRTO et al., 2011; ZUFFO et al., 2012). The readings were performed between 9 and 11 a.m. in the median portion of the leaf limb of all plants in the useful plot area. In each plant, three measurements were taken using the portable SPAD-502 chlorophyll meter.

Harvests began on the $33^{\text {rd }}$ DAS, extending up to $54 \mathrm{DAS}$, and were carried out when the fruits reached the commercial harvest point. The fruits were evaluated for diameter $(\mathrm{cm})$, length $(\mathrm{cm})$, fresh mass (g), dry mass $(\mathrm{g})$, and total productivity (g/plant). To evaluate these characteristics, the following were used: a digital caliper, with $0.01-\mathrm{mm}$ accuracy, and an AL 500C model scale, with an accuracy of $0.001 \mathrm{~g}$.

On the $54^{\text {th }}$ DAS, the plants were removed from the system and evaluated for length $(\mathrm{cm})$, fresh and dry mass of the aerial part (g), and number of leaves per plant. The fresh mass of the aerial part was also added to the mass of the small fruits, that is, of non-commercial size fruit. The obtained data were submitted to analysis of variance, and the means were compared by the Tukey test at $5 \%$ probability using SAEG software (2007). 


\section{RESULTS AND DISCUSSION}

According to the synthesis of the analysis of variance, a significant effect was found for the nutrient solutions for the following characteristics: SPAD index, number of shoots per plant, fruit diameter, fruit fresh and dry matter mass, fresh and dry matter mass of the aerial part, and length of cucumber plants. A significant effect of hybrids was found on the following characteristics: fruit size and number of shoots, length, diameter, and fruit fresh mass. The fresh and dry mass of the aerial part and the length of the plants were also significant (Table 1).

Table 1. Analysis of variance synthesis for the evaluated characteristics of SPAD index (soil plant analysis development), number of shoots (NS), fruit length (FL), fruit diameter (FD), fruit fresh mass (FFM), fruit dry mass (FDM), fresh mass of the aerial part (FMAP), dry mass of the aerial part (DMAP), number of leaves (NL), yield per plant (YIELD), and length of the plant (LP) in function to two cucumber hybrids and four nutritional solutions in a hydroponic system.

\begin{tabular}{|c|c|c|c|c|c|c|c|c|c|c|c|c|}
\hline $\mathrm{SV}^{(1)}$ & DF & SPAD & NS & FL & FD & FFM & FDM & FMAP & DMAP & NL & YIELD & LP \\
\hline \multicolumn{13}{|c|}{ MEAN SQUARES } \\
\hline $\mathrm{S}$ & 3 & $46.5^{* *}$ & $9.1 * *$ & $2.1^{\mathrm{ns}}$ & $8.7 * *$ & $2518.4 * *$ & $3.5 * *$ & $237349.5^{* *}$ & $1643.7^{* *}$ & $5.0^{\mathrm{ns}}$ & 526065.6 & $4263.7 * *$ \\
\hline $\mathrm{Ea}$ & 9 & 0.6 & 1.1 & 2.3 & 1.0 & 243.3 & 0.6 & 7304.8 & 23.5 & 1.5 & 43609.0 & 55.6 \\
\hline $\mathrm{H}$ & 1 & $8.0^{\mathrm{ns}}$ & $7.5^{*}$ & $113.3^{* *}$ & $8.2^{*}$ & $3554.8 * *$ & $1.6^{\mathrm{ns}}$ & $81075.6^{* *}$ & $583.9^{* *}$ & $1.2^{\mathrm{ns}}$ & $386016.7^{\mathrm{ns}}$ & $1181.5^{* *}$ \\
\hline $\mathrm{S} * \mathrm{H}$ & 3 & 1.5 & $0.6^{\mathrm{ns}}$ & $3.1^{\mathrm{ns}}$ & $1.9^{\mathrm{ns}}$ & $400.3^{\mathrm{ns}}$ & 0.2 & $9804.3^{\mathrm{ns}}$ & $22.2^{\mathrm{ns}}$ & $2.8^{\mathrm{ns}}$ & $21199.4 * *$ & $365.6^{\mathrm{ns}}$ \\
\hline $\mathrm{Eb}$ & 12 & 3.1 & 1.1 & 2.0 & 1.2 & 195.1 & 0.6 & 5036.2 & 37.2 & 2.9 & 28508.4 & 122.9 \\
\hline Mean & & 40.0 & 3.7 & 18.3 & 34.8 & 147.8 & 4.3 & 443.3 & 52.7 & 16.9 & 517.7 & 144.3 \\
\hline $\mathrm{CVa}$ & & 2.0 & 28.1 & 8.3 & 2.9 & 10.6 & 18.0 & 19.3 & 9.2 & 7.2 & 40.3 & 5.2 \\
\hline $\mathrm{CVb}$ & & 4.4 & 28.6 & 7.8 & 3.2 & 9.5 & 18.5 & 16.0 & 11.6 & 10.1 & 32.6 & 7.7 \\
\hline
\end{tabular}

${ }^{(1)} \mathrm{SV}$ - Sources of variation; S - Solutions; Error a - Solutions residue; H - Hybrids; $\mathrm{S} * \mathrm{C}$ - Interaction between solutions and hybrids; Error $\mathrm{b}$ - Hybrids residue; $\mathrm{CVa}$ - Coefficient of variation of solutions; $\mathrm{CVb}$ - Coefficient of variation of the hybrids; DF - Degrees of freedom;

${ }^{(2)} \mathrm{ns}-$ Not significant; **and *Significant at the level of $1 \%$ and $5 \%$ probability by the $\mathrm{F}$ test.

The value of the SPAD index was inversely related to the concentration of $\mathrm{K}$ in the nutrient solution, which was significantly higher in the nutrient solution with the lowest concentration of $\mathrm{K}$, that is, in the highest $\mathrm{N}: \mathrm{K}$ ratio $(1: 0.5)$ (Table 2). A higher amount of $\mathrm{N}$ was found in this solution and probably a higher content of chlorophyll, associated with the green color of the leaves, as measured by the chlorophyll meter. Some authors report that the content of chlorophyll correlates with the concentration of $\mathrm{N}$ in the plant (GÜLER; BÜYÜK, 2007; PÔRTO et al., 2011) and with the yield of several species (MOREIRA et al. 2011), and it can be used as a tool to aid in the nitrogen fertilization of crops (MOREIRA et al., 2011; PÔRTO et al., 2011).

Table 2. SPAD index, number of shoots per plant (NS), number of leaves (NLE), fruit length (FL), fruit diameter (FD), fruit fresh mass (FFM), fruit dry mass (FDM), fresh mass of the aerial part (FMAP), dry mass of the aerial part (DMAP) and length of the plant (LP) in cucumber plants grown in an NFT-hydroponic system in nutritional solutions with different $\mathrm{N}: \mathrm{K}$ ratios.

\begin{tabular}{ccccccccccc}
\hline N:K RATIO SPAD & NS & NLE & FL $(\mathrm{CM})$ & FD $(\mathrm{cm})$ & FFM $(\mathrm{g})$ & FDM $(\mathrm{G})$ & FMAP $(\mathrm{G})$ & DMAP (G) LP (CM) \\
\hline $1: 0.5$ & $43.5 \mathrm{a}$ & $2.3 \mathrm{~b}$ & $16.1 \mathrm{a}$ & $18.5 \mathrm{a}$ & $33.8 \mathrm{c}$ & $137.7 \mathrm{~b}$ & $3.6 \mathrm{~b}$ & $240 \mathrm{~d}$ & $35.8 \mathrm{~d}$ & $115.2 \mathrm{c}$ \\
$1: 1.0$ & $39.2 \mathrm{~b}$ & $3.5 \mathrm{ab}$ & $16.4 \mathrm{a}$ & $17.8 \mathrm{a}$ & $34.0 \mathrm{bc}$ & $131.6 \mathrm{~b}$ & $3.9 \mathrm{ab}$ & $375 \mathrm{c}$ & $46.9 \mathrm{c}$ & $137.6 \mathrm{~b}$ \\
$1: 2.0$ & $38.5 \mathrm{~b}$ & $4.0 \mathrm{a}$ & $17.5 \mathrm{a}$ & $18.2 \mathrm{a}$ & $5.6 \mathrm{ab}$ & $149.9 \mathrm{~b}$ & $4.4 \mathrm{ab}$ & $524 \mathrm{~b}$ & $59.2 \mathrm{~b}$ & $156.8 \mathrm{a}$ \\
$1: 3.0$ & $38.5 \mathrm{~b}$ & $4.8 \mathrm{a}$ & $17.5 \mathrm{a}$ & $19.0 \mathrm{a}$ & $35.9 \mathrm{a}$ & $171.7 \mathrm{a}$ & $5.2 \mathrm{a}$ & $634 \mathrm{a}$ & $68.7 \mathrm{a}$ & $167.7 \mathrm{a}$ \\
\hline Means & 39.9 & 3.7 & 16.9 & 18.4 & 34.8 & 147.7 & 4.3 & 443.3 & 52.6 & 144.3 \\
$\mathrm{CV}$ & 4.39 & 28.55 & 10.13 & 7.77 & 3.17 & 9.45 & 18.46 & 16.01 & 11.58 & 7.68 \\
\hline
\end{tabular}

Means followed by the same letters in the columns are not different from each other by the Tukey test at $5 \%$ probability.

The number of shoots per plant increased as the concentration of potassium increased in the nutrient solution, whereas the number of leaves did not differ between the solutions (Table 2). That is, the increase in the number of shoots with the concentration of $\mathrm{K}$ in the solution did not significantly increase the number of leaves per plant, up to the $54^{\text {th }}$ DAS. However, for melon grown in a semi-hydroponic system, higher potassium concentrations in the nutrient solutions applied to the substrate increased the number of leaves in plants at 7 to 67 days after transplant (QUEIROZ, 2016).

The length of the fruit was not influenced by nutrient solutions with different $\mathrm{N}: \mathrm{K}$ ratios, whose mean value was $18.4 \mathrm{~cm}$. On the other hand, significant differences $(p<0.05)$ were found for fruit diameter, where the highest values were obtained in the solutions with the highest concentrations of $\mathrm{K}$ (Table 2). This increase in the diameter of the fruit with the concentration of $\mathrm{K}$ is probably related to the 
demands by the plants for this nutrient. Potassium is vital for photosynthesis, promotes the formation and translocation of carbohydrates and the efficient use of water by the plant, and improves the quality of the product and, consequently, its market value (FILGUEIRA, 2008). Situations of deficiency cause a reduction of the photosynthetic rate and increase in respiration, resulting in a decrease in the accumulation of carbohydrates (NOVAIS et al., 2007). An increase in fruit diameter was also observed in cucumber of the Aodai group, in hydroponic cultivation (FERNANDES; MARTINEZ; OLIVEIRA, 2002), and in melon grown in a semi-hydroponic system with different concentrations of potassium in the nutrient solution (QUEIROZ, 2016).

The fresh and dry mass of the fruits and the fresh and dry mass of the aerial part of the plants were significantly higher in the $\mathrm{N}: \mathrm{K}$ ratio equal to $1: 3.0$, that is, the highest concentration of $K$ in the nutrient solution positively influenced the production of fresh and dry mass of the fruit and of the aerial part of the plant (Table 2). Pedrosa et al. (2011) observed a low production of fresh mass of cucumber fruits when the fruiting solution presented an $\mathrm{N}: \mathrm{K}$ ratio of $1: 1.4$; a better performance was found by altering the $\mathrm{N}: \mathrm{K}$ ratio of $1: 1.4$ in the vegetative phase to $1: 2.0$ in the reproductive phase. Potassium is known to be fundamental to growth and production, since it plays important roles in plants, such as photosynthesis, enzymatic activation, protein synthesis, and carbohydrate translocation to fruits (TAIZ; ZEIGER, 2013).

Knowledge of the normal patterns of dry and fresh mass accumulation by a crop allows a better understanding of the factors related to plant nutrition. In this work, the highest production of fresh and dry matter of the aerial part of the plant is related to the larger number of buds and small fruits, since the number of leaves did not differ among the nutritional solutions. Such characteristics were favored by the greater availability of nutrients, especially $\mathrm{K}$, in the solutions.

Regarding the average length of plants, higher values were found in the $\mathrm{N}: \mathrm{K}$ ratios of $1: 2.0$ and $1: 3.0$, that is, at the highest concentrations of $\mathrm{K}$ (Table 2). Similar results were recorded by Queiroz (2016), who evaluated the growth of net melon in a semi-hydroponic system and verified an increase in plant height as potassium concentration increased; in other words, the higher the potassium concentration in the nutrient solution, the higher the mean height of the plants at the end of the cycle.

Fruit yield was higher when the fruiting nutritive solution presented $\mathrm{N}: \mathrm{K}$ ratios of 1:2.0 and 1:3.0 in both Natsuno Kagayaki and Runner hybrids (Table 3 ). These results corroborate those presented by Fernandes, Martinez e Oliveira (2002), who observed an increase in the yield of cucumber fruits (Aodai) when an $\mathrm{N}: \mathrm{K}$ ratio of $1: 1.4$ was altered in the vegetative phase to $1: 2.0$ in the reproductive phase. In melon grown in a semi-hydroponic system, Queiroz (2016) also observed a higher average fruit mass and higher productivity when the potassium concentration in the nutrient solution was increased.

In the 1:3.0 ratio, the Natsuno Kagayaki and Runner hybrids presented average yields of $972.15 \mathrm{~g}$ and $670.9 \mathrm{~g}$ per plant, respectively, for a 54-day cycle. On the other hand, Pedrosa et al. (2011), when working with hybrids of Aodai cucumber in a hydroponic system, obtained average productivities of $3500 \mathrm{~g}$ per plant in an 87-day cycle. Moreover, Pedrosa et al. (2011) obtained productivity of 1348.2 $\mathrm{g}$ for a 90-day cycle when they altered the $\mathrm{N}: \mathrm{K}$ ratio of $1: 1.4$ to $1: 2.0$ in the vegetative phase and $1: 1.7$ in the reproductive phase. The higher productivity obtained by these authors is attributed mainly to the longer cycle length, which implies a larger number of harvests.

According to the fruit productivity results, the Natsuno Kagayaki hybrid was the most productive, differing significantly from the Runner at $\mathrm{N}: \mathrm{K}$ ratios of $1: 2.0$ and $1: 3.0$, with a gain of over $30 \%$ (Table 3 ). Higher yields obtained with the Natsuno Kagayaki hybrid were also verified by Sediyama et al. (2014) when they studied three cucumber hybrids and different types of pruning in field conditions.

Table 3. Fruit yield $\left(\mathrm{g} \mathrm{plant}^{-1}\right)$ of fruits from two cucumber hybrids in an NFT-hydroponic system grown in different N:K systems in fruiting nutritional solutions.

\begin{tabular}{cccr}
\hline \multirow{2}{*}{$\mathrm{N}:$ K ratio } & \multicolumn{3}{c}{ Cucumber hybrids } \\
\cline { 2 - 4 } & Natsuno Kagayaki & Runner & Means \\
\hline $1: 0.5$ & $400.34 \mathrm{bA}$ & $308.08 \mathrm{bA}$ & 354.21 \\
$1: 1.0$ & $352.54 \mathrm{bA}$ & $172.66 \mathrm{bA}$ & 262.60 \\
$1: 2.0$ & $785.06 \mathrm{aA}$ & $479.80 \mathrm{abB}$ & 632.43 \\
$1: 3.0$ & $972.15 \mathrm{aA}$ & $670.90 \mathrm{aB}$ & 821.53 \\
\hline Means & 627.52 & 407.86 & \\
\hline $\mathrm{CV}(\%)$ & & 32.62 &
\end{tabular}

Means followed by the same lowercase letter in the columns and uppercase letters in the rows are not different from each other by the Tukey test at $5 \%$ probability. 
In relation to the hybrids, no significant differences were found for the following characteristics: number of shoots, length and diameter of fruits, fresh matter of fruits, fresh and dry matter of the aerial part, and length of plant (Table 4). The Runner hybrid showed a higher number of shoots than Natsuno. This hybrid also showed higher fresh and dry matter of the aerial part, which may be associated to the number of shoots on the plants. No significant difference was observed between hybrids for the SPAD index, fruit dry matter, and number of leaves per plant (Table 4).

Table 4. SPAD index, number of shoots per plant (NS), fruit length (FL), fruit diameter (FD), fruit fresh mass (FFM), fruit dry mass (FDM), fresh mass of the aerial part (FMAP), dry mass of the aerial part (DMAP), number of leaves per plant (NLE) and length of the plant (LP) of two cucumber hybrids grown in an NFT-hydroponic system.

\begin{tabular}{ccccccccccc}
\hline Cucumber hybrids & SPAD & NS & FL $(\mathrm{cm})$ & FD $(\mathrm{cm})$ & FFM (G) & FDM $(\mathrm{g})$ & FMAP $(\mathrm{g})$ & DMAP $(\mathrm{g})$ & NLE & LP $(\mathrm{cm})$ \\
\hline Natsuno Kagayaki & $40.5 \mathrm{a}$ & $3.16 \mathrm{~b}$ & $20.3 \mathrm{a}$ & $34.3 \mathrm{~b}$ & $158.3 \mathrm{a}$ & $4.0 \mathrm{a}$ & $392.9 \mathrm{~b}$ & $48.4 \mathrm{~b}$ & $16.7 \mathrm{a}$ & $138.3 \mathrm{~b}$ \\
Runner & $39.4 \mathrm{a}$ & $4.13 \mathrm{a}$ & $16.5 \mathrm{~b}$ & $35.3 \mathrm{a}$ & $137.2 \mathrm{~b}$ & $4.5 \mathrm{a}$ & $493.6 \mathrm{a}$ & $56.9 \mathrm{a}$ & $17.1 \mathrm{a}$ & $150.4 \mathrm{a}$ \\
Means & 39.9 & 3.6 & 18.3 & 34.8 & 147.7 & 4.3 & 443.3 & 52.7 & 16.9 & 144.4 \\
\hline CV(\%) & 4.39 & 28.55 & 7.77 & 3.17 & 9.45 & 18.46 & 16.01 & 11.58 & 10.13 & 7.68 \\
\hline
\end{tabular}

Means followed by the same letters in the columns are not different from each other by the Tukey test at $5 \%$ probability.

Overall, the hybrid Natsuno Kagayaki excelled in relation to Runner for length and fresh matter of the fruits. These characteristics are associated with productivity and are likely to have contributed to higher fruit productivity in the Natsuno Kagayaki hybrid. Another advantage of this hybrid is the lower number of shoots per plant, a characteristic that facilitates the conduction of plants in the hydroponic system.

The average yields were 627.52 and 407.86 g plant $^{-1}$ for the Natsuno and Runner hybrids, respectively, which were obtained over a period of 54 days. The difference in fruit yield in the two hybrids was expected, since they belong to different groups. The best results for cucumber from the Japanese group are probably due to the fact that it is a parthenocarpic hybrid (seedless) variety.

The Runner hybrid belongs to the Aodai group, which is not parthenocarpic, making it difficult to plant them in closed greenhouses due to the lower entry of pollinating insects (CARDOSO, 2007) and the consequent decrease in productivity. Although the Runner hybrid is less productive in relation to Natsuno Kagayaki, this is probably due to the presence of pollinating insects inside the greenhouse, such as the presence of ants in flowers. Despite the small number of references in the literature mentioning the need to change the concentration of the nutrient solution for cucumber cultivation, the highest $\mathrm{N}: \mathrm{K}$ ratio in the fruiting phase improves the diameter, fresh and dry mass, and fruit yield for both hybrids.

\section{CONCLUSIONS}

For hydroponic cucumber cultivation, the best concentrations of $\mathrm{N}: \mathrm{K}$ of the fruiting nutrient solution are 1:2.0 and 1:3.0 (w/w). The higher concentration of potassium $(\mathrm{K})$ in the nutrient solution increases the diameter, fruit mass, and productivity, especially for the hybrid Natsuno Kagayaki, Japanese group.

\section{ACKNOWLEDGMENTS}

We thank the Foundation for Research Support of the State of Minas Gerais (FAPEMIG) for funding the research and granting scholarships, and the CNPq for the productivity grant.

\section{REFERENCES}

ACOSTA, P. P. L. et al. Efecto de diferentes concentraciones de potasio y nitrógeno em la productividad de tomate em cultivo hidropônico. Tecnociencia chihuahua, Chihuahua, v. 5 , n. 2 , p. 98-104, 2011.

ADAMS, P. Nutrition of greenhouse vegetables in NFT and hydroponic systems. Acta Horticulturae, Wageningen, v. 1, n. 361, p. 245-257, 1994.

AQUINO, L. A. et al. Produção de biomassa, teor e exportação de macronutrientes em plantas de repolho em função de doses de nitrogênio e de espaçamentos. Ciência e Agrotecnologia, Lavras, v. 33, n. 5, p. 1295-1300, 2009.

BETTIOL, W.; ASTIARRAGA, B. D.; LUIZ, A. J. B. Effectiveness of cow's milk against zucchini squash powdery mildew (Sphaerotheca fuliginea) in greenhouse conditions. Crop Protection, Guidford, v.18, n. 8, p. 489-492, 1999.

CARDOSO, A. I. I. Avaliação de linhagens e híbridos experimentais de pepino do grupo varietal japonês sob ambiente protegido. Bragantia, Campinas, v. 66, n. 3, p. 469-475, 2007. 
FERNANDES, A. A.; MARTINEZ, H. E. P.; OLIVEIRA, L. R. Produtividade, qualidade dos frutos e estado nutricional de plantas de pepino cultivadas em hidroponia, em função das fontes de nutrientes. Horticultura Brasileira, Brasília, v. 20, n. 4, p. 571-575, 2002.

FILGUEIRA, F. A. R. Novo manual de olericultura: agrotecnologia moderna na produção e comercialização de hortaliças. 3. ed. Viçosa, MG: Universidade Federal de Viçosa, 2008. $421 \mathrm{p}$.

FURLANI, P. R. et al. Nutrição mineral de hortaliças, preparo e manejo de soluções nutritivas. Informe Agropecuário, Belo Horizonte, v. 20, n. 200-201, p. 90-98, 1999.

GÜLER, S.; BÜYÜK, G. Relationships among chlorophyll-meter reading value, leaf $\mathrm{N}$ and yield of cucumber and tomatoes. Acta Horticulturae, Wageningen, v. 729, n. 50, p. 307-311, 2007.

MARTINEZ, H. E. P.; SILVA FILHO, J. B. Introdução ao cultivo hidropônico de plantas. Viçosa, MG: Universidade Federal de Viçosa. 1997. $52 \mathrm{p}$.

MARTINS, C. M. et al. Curva de absorção de nutrientes em alface hidropônica. Revista Caatinga, Mossoró, v. 22, n. 4, p. 123-128, 2009.

MOREIRA, M. A. et al. Índices para avaliar o estado de nitrogênio da batata multiplicada por distintos materiais propagativos. Revista Ceres, Viçosa, v. 58, n. 3, p. 384-392, 2011.

NOVAIS, R. F. et al. Fertilidade do solo. 1. ed. Viçosa, MG. SBCS, 2007. 1017 p.

PEDROSA, A. W. et al. Influence of the $\mathrm{N} / \mathrm{K}$ ratio on the production and quality of cucumber in hydroponic system. Revista Ceres, Viçosa, v. 58, n. 5, p. 619-624. 2011.

PÔRTO, M. L. et al. Índice SPAD para o diagnóstico do estado de nitrogênio na cultura da abobrinha. Horticultura Brasileira, Brasília, v. 29, n. 3, p. 311-315, 2011.

QUEIROGA, R. C. F. et al. Influência de doses de nitrogênio na produtividade e qualidade do melão Cantalupensis sob ambiente protegido. Horticultura Brasileira, Brasília, v. 25, n. 4, p. 550-556, 2007.

QUEIROZ, I. S. R. Cultivo do meloeiro em sistema semihidroponico sob diferentes concentrações de potássio na solução nutritiva. 2016. 72 f. Dissertação (Mestrado em Ciências Ambientais e Tecnológicas. Área de concentração em Manejo de
Solo e Água) - Universidade Federal Rural do Semi-Árido, Mossoró, 2016.

SAEG. Sistema para Análise Estatística. Versão 9,1: Fundação Artur Bernardes-UFV, Viçosa-MG, 2007.

SEDIYAMA, M. A. N. et al. Tipos de poda em pepino dos grupos aodai, japonês e caipira. Horticultura Brasileira, Brasília, v. 32, n. 4, p. 491-496, 2014

TAIZ, L.; ZEIGER, E. Fisiologia vegetal. 5. ed. Porto Alegre, RS: ARTMED. 2013. 954 p.

ZUFFO, A. M. et al. Eficiência na determinação indireta do nitrogênio foliar a partir do índice SPAD. Enciclopédia Biosfera, Goiânia, v. 8, n. 15; p. 802-820, 2012. 